\title{
Angiotensin-Converting Enzyme Gene Insertion/Deletion Polymorphism and Left Ventricular Hypertrophy in Hemodialysis Patients
}

\author{
Toshihiro Nagahara, MD, Tomoaki Ishigami, ${ }^{1} \mathrm{MD}$, \\ Toshio Sano, MD, Yumiko IkeDa, MD, \\ Kiyoshi HrbI, ${ }^{1}$ MD, Susumu Uneda, ${ }^{2} \mathrm{MD}$, \\ Satoshi UMEMURA, ${ }^{\prime} \mathrm{MD}$, \\ and Masao IsHII, ${ }^{1} \mathrm{MD}$
}

\section{SUMMARY}

The relationships between angiotensin-converting enzyme (ACE) gene insertion (I) / deletion (D) polymorphism and left ventricular hypertrophy induced by hypertension or idiopathic hypertrophic cardiomyopathy have been studied. However, little is known about the association between this polymorphism and left ventricular hypertrophy induced by volume overload.

The relationship between left ventricular hypertrophy and the ACE gene I/D polymorphism was examined in 80 maintenance hemodialysis patients (mean age: $60.1 \pm 1.4<\mathrm{SEM}>$ years).

Multivariate regression analysis showed that the left ventricular mass index calculated by $M$-mode echocardiography was associated with serum creatinine $(p=0.040)$, male gender $(p=0.027)$, antihypertensive drug treatment $(p=0.026)$, weight gain between hemodialysis $(p=0.018)$ and mean blood pressure after hemodialysis $(p=0.010)$, but not with ACE I/D genotype $(p=0.69)$.

These findings suggest that although hemodialysis patients seem to be under volume overload, ACE genotype may not be involved in their left ventricular hypertrophy. Hypertension and other factors related to renal failure are involved in the left ventricular hypertrophy in chronic hemodialysis patients. (Jpn Heart J 1997; 38: 821-830)

Key words: ACE gene polymorphism, Hypertrophy, Left ventricular, Echocardiography, Left ventricular mass, Hemodialysis $(\mathrm{LVH})$ is a major predictor of death from cardiovascular diseases. ${ }^{1,2)}$ Fur-

From the Second Department of Internal Medicine, Yokohama Minami Kyosai Hospital, Yokohama, 'Second Department of Internal Medicine, Yokohama City University School of Medicine, Yokohama, and ${ }^{2}$ Kousaikai Kanazawa Clinic, Yokohama, Japan.

Address for correspondence: Satoshi Umemura, MD, Second Department of Internal Medicine, Yokohama City University School of Medicine, 3-9, Fukuura, Kanazawa-Ku, Yokohama 236, Japan.

Received for publication August 25, 1997.

Accepted September 12, 1997. 
thermore, among maintenance hemodialysis (HD) patients, LVH is common because of volume overload and hypertension resulting from renal disease. ${ }^{3,4)}$ Heart diseases account for approximately $40 \%$ of all causes of death in maintenance HD patients. ${ }^{3,5)}$ Therefore, LVH seems to be a very important factor that worsens their prognosis.

The renin-angiotensin system has been shown to be an important system that regulates blood pressure and homeostasis of body fluid, and abnormalities in the system may be involved in the development of cardiovascular diseases. Recently, several gene polymorphisms, such as the ACE, angiotensinogen and angiotensin II type 1 receptor genes, have been reported to be associated with cardiovascular disorders by many investigators, including our group. ${ }^{6)}$ In particular, since Cambiens et al. reported the association of this ACE gene polymorphism with the development of myocardial infarction, ${ }^{7)} \mathrm{ACE}$ gene I/D polymorphism has been shown to be associated with not only ischemic heart disease ${ }^{8,9}$ but also $\mathrm{LVH}^{10,11)}$ cardiomyopathy, ${ }^{12)}$ cerebral infarction, ${ }^{13)}$ diabetic nephropathy ${ }^{14)}$ and restenosis after PTCA. ${ }^{15)}$ However, opposite findings have also been reported. ${ }^{16,17)}$

Although there have been many studies examining the relationship between ACE gene polymorphism and LVH, the subjects were from general populations free of advanced renal failure. Studies in patients who are under volume overload, such as HD patients, have never been studied. Compared to hypertensive patients with $\mathrm{LVH}$, maintenance $\mathrm{HD}$ patients are exposed to prominent volume overload because of renal failure and arterio-venous fistula. ${ }^{18}$ The involvement of the ACE gene polymorphism in LVH may be different in these patients from those with LVH induced by pressure overload. In order to study the involvement of ACE gene polymorphism in volume overload induced $\mathrm{LVH}$, we examined it in maintenance HD patients and attempted to identify factors which are involved in $\mathrm{LVH}$ in these patients.

\section{Subjects and Methods}

Patient population: The subjects were randomly selected from patients who had been under maintenance HD. Patients who had a history of myocardial infarction, valvular heart disease or dilated cardiomyopathy were excluded from the study. Eighty patients, aged from 40 to 72 years old, were subsequently enrolled in the study. Informed consent was obtained after thorough explanation of the purpose and protocol of the study. Causative renal diseases included chronic glomerulonephritis (29\%), diabetic nephropathy (38\%) and nephrosclerosis (13\%). History of hypertension was positive in 58 of the 80 patients and 33 were under antihypertensive treatment. The duration of $\mathrm{HD}$ was 
from 3.7 to 8.0 years (mean 6.2 years).

The patients underwent HD 3 times a week, each performed for approximately 3 hours. Blood pressure was measured with a sphyngomanometer in a supine position. A standard 12-lead electrocardiogram (ECG), chest X-ray film and echocardiogram were taken before HD.

Echocardiography: Echocardiography was performed using a SSH140A system with a $2.5 \mathrm{MHz}$ or $3.75 \mathrm{MHz}$ probe (Toshiba Medical Corp, Tokyo) just before HD.

Under 2-dimensional guidance, LVM was calculated from M-modc echocardiographic measurements of left ventricular diastolic diameter (LVDd), interventricular septum (IVSd) and left ventricular posterior wall thickness (LVPWd) at end-diastole, according to the recommendations of the American Society of Echocardiography. The formula of Devereux and Reichek ${ }^{19)}$ was used to estimate LVM as follows:

$$
\mathrm{LVM}(\mathrm{g})=1.04\left[(\mathrm{LVDd}+\mathrm{IVSd}+\mathrm{LVPWd})^{3}-(\mathrm{LVDd})^{3}\right]-13.6 .
$$

Body surface area (BSA) was estimated based on the Fujimoto and Watanabe equation:

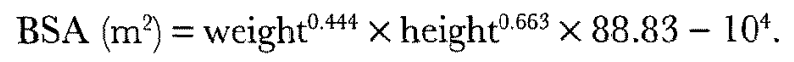

A LVM index (LVMI) was obtained by dividing LVM by body surface area. As mentioned above, when valvular stenosis or regurgitation was found by 2-dimensional echocardiography or Doppler echocardiography in the mitral valve or aortic valve, the patient was excluded from the study.

Genotype determination: Approximately $7 \mathrm{ml}$ of blood were collected into a cold test tube containing EDTA from a dialysis circuit during HD. DNA was extracted using a DNA extraction reagent kit, DnaQuick (Dainippon Pharmaceutical Co., Ltd., Tokyo). ACE genotype was determined using the PCR methods according to a protocol reported previously. ${ }^{20)}$ The sense oligonucleotide primer was 5'-GAT GTG GGG ATG AGA TTG GTG AGAT-3' and the antisense primer 5'-CTG GAG ACC ACT CCC ATC CTT TCT-3'. The reaction was performed using $25 \mathrm{pmol}$ primer, $1.5 \mathrm{mmol} / l \mathrm{MgCl}_{2}, 50 \mathrm{mmol} / l \mathrm{KCl}$,

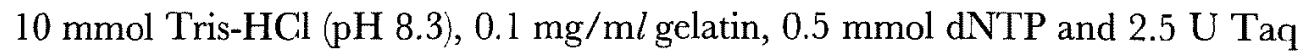
polymerase. To prevent mistyping, $5 \%$ DMSO was added to this mixture. Amplification was carried out in a DNA Thermal Cycler (PJ2400, Perkin-Elmer Corp., Norwalk, Conn, USA) for 30 cycles of denaturation at $93^{\circ} \mathrm{C}$ for 1 minute, annealing at $58^{\circ} \mathrm{C}$ for 1 minute, and extension at $72^{\circ} \mathrm{C}$ for 1 minute. DNA was visualized after electrophoresing the PCR products on $1.6 \%$ agarose gels and staining with ethidium bromide. ACE polymorphism was demonstrated by the presence of a 190-bp fragment, deletion (D) allele, and a 490-bp fragment, inser- 
tion (I) allele. Finally, genotypes were determined in 80 of 88 cases from whom high quality echocardiograms had been obtained.

Statistical Analysis: The following factors which may be related to LVMI were examined: gender, age, history of hypertension, the presence or absence of antihypertensive drug treatment, duration of $\mathrm{HD}$, causative renal disease, blood pressure, heart rate, average weight gain between each dialysis, average fluid depletion during dialysis, electrocardiographic findings, cardiothoracic ratio (CTR), laboratory data (scrum concentrations of $\mathrm{Na}, \mathrm{K}, \mathrm{Cl}, \mathrm{Ca}, \mathrm{P}$, total protein, blood urea nitrogen, creatinine and uric acid, and hematocrit) and ACE genotype.

ANOVA methods were used with StatView 4.11 software for Macintosh to compare LVMI among subgroups according to ACE genotype. Multiple linear regression analysis methods were used with SPSS for Macintosh to analyze LVMI precisely.

\section{Results}

Chronic glomerulonephritis and diabetic nephropathy were the two major causative renal diseases, as is consistent with the prevalence reported in Japan. ${ }^{21)}$ Thirty-three of 58 patients who had a history of hypertension were taking antihypertensive drugs. No significant differences in the distribution of ACE genotype were found in relation to gender, history of hypertension or causative renal disease.

In the analyses of variance of LVMI among ACE genotype subgroups,

Table 1. Left Ventricular Mass Index in ACE Genotypes and Clinical Subgroups

\begin{tabular}{|c|c|c|c|c|c|}
\hline \multirow[t]{2}{*}{ Subjects } & \multicolumn{5}{|c|}{ ACE genotype } \\
\hline & Total & DD & ID & II & $p$ \\
\hline Total subject population & $188.5 \pm 6.7 \quad(80)$ & $183.4 \pm 13.3(8)$ & $193.5 \pm 12.5(30)$ & $185.9 \pm 8.9$ & 0.84 \\
\hline \multicolumn{6}{|l|}{ History hypertension } \\
\hline without hypertension & $169.8 \pm 10.5(22)$ & $186.0 \quad$ (I) & $182.6 \pm 27.0(7)$ & $162.1 \pm 9.9(14)$ & 0.18 \\
\hline with hypertension & $195.7 \pm 8.2$ & $183.1 \pm 15.3(7)$ & $196.9 \pm 14.4(23)$ & $197.8 \pm 11.8(28)$ & 0.75 \\
\hline \multicolumn{6}{|l|}{ Antihypertensive drugs } \\
\hline no & $173.6 \pm 7.5 \quad(47)$ & $195.9 \pm 19.5(4)$ & $179.2 \pm 16.1(15)$ & $167.4 \pm 8.8 \quad(28)$ & 0.52 \\
\hline yes & $209.9 \pm 11.4(33)$ & $171.0 \pm 18.3(4)$ & $208.0 \pm 19.0(15)$ & $223.0 \pm 16.3\langle 14\rangle$ & 0.38 \\
\hline \multicolumn{6}{|l|}{ Gender } \\
\hline male & $197.4 \pm 7.9$ & $197.0 \pm 12.9(5)$ & $211.6 \pm 16.7(19)$ & $193.8 \pm 10.1(33)$ & 0.82 \\
\hline female & $166.6 \pm 11.6(23)$ & $148.3 \pm 27.7(2)$ & $176.8 \pm 18.4(12)$ & $157.2 \pm 16.2(9)$ & 0.67 \\
\hline \multicolumn{6}{|l|}{ Weight gain } \\
\hline above or equal to median & $203.3 \pm 9.7 \quad$ (44) & $198.3 \pm 18.0(4)$ & $215.2 \pm 18.2(15)$ & $196.9 \pm 13.0(25)$ & 0.69 \\
\hline below median & $170.5 \pm 8.1$ & $168.5 \pm 18.8(4)$ & $171.8 \pm 16.0(15)$ & $169.8 \pm 9.8 \quad(17)$ & 0.99 \\
\hline
\end{tabular}

Values are means \pm SEM. The number of patients in each subgroup is shown in parentheses. The median value for weight gain between hemodialysis is $1.7 \mathrm{~kg}$. $\mathrm{HD}=$ hemodialysis; $\mathrm{DD}=$ deletion/deletion; ID = insertion/deletion; II = insertion/insertion. 
Table II. Multivariate Analysis of LVMI

\begin{tabular}{lccccc}
\hline \multicolumn{1}{c}{ Variable } & B & SEB & Beta & T & $p$ \\
\hline Age & -0.063 & 0.572 & -0.013 & -0.109 & 0.91 \\
ACE genotype & -3.797 & 9.343 & -0.043 & -0.406 & 0.69 \\
Serum creatinine & -4.976 & 2.381 & -0.253 & -2.09 & $0.04^{*}$ \\
Hematocrit & -0.411 & 1.503 & -0.027 & -0.274 & 0.79 \\
HD duration & 0.275 & 1.266 & 0.024 & 0.217 & 0.83 \\
Antihypertensive drugs & 28.369 & 12.467 & 0.235 & 2.276 & $0.03^{*}$ \\
Gender & 32.667 & 14.437 & 0.249 & 2.263 & $0.03^{*}$ \\
Weight gain & 22.844 & 9.419 & 0.245 & 2.425 & $0.02^{*}$ \\
Mean BP after HD & 1.541 & 0.582 & 0.307 & 2.647 & $0.01^{*}$ \\
(Constant) & 42.338 & 94.746 & & 0.447 & 0.66 \\
\hline
\end{tabular}

LVMI; regression $\mathrm{df}=9, \mathrm{~F}=3.803, \mathrm{p}=0.0006 . \mathrm{ACE}=$ angiotensin converting enzyme; $\mathrm{HD}=$ hemodialysis; $\mathrm{BP}=$ blood pressure. $* p<0.05$.

there were no significant differences in LVMI among the entire subject population or among the clinical subgroups (Table I). However, when LVMI was analyzed in clinical subgroups ignoring the ACE genotype, there were significant differences in LVMI between males and females $(p=0.04)$, between the presence and absence of antihypertensive drug treatment $(p=0.007)$ and between above or equal to and below median value of weight gain during each hemodialysis interval $(p=0.01)$. When analyzed by multiple linear regression analysis, LVMI exhibited a significant relationship with serum creatinine, male gender, the presence of antihypertensive drug treatment, averaged weight gain between two successive HDs and mean blood pressure after HDs, but not with age, ACE genotype, hematocrit or duration of HD (Table II). Although we also performed other multiple linear regression analyses which took into consideration ACE genotype, history of hypertension, clinical characteristics, laboratory data, CTR and HD data as independent variables, LVMI was found to have no definite relationship with any.

\section{Discussion}

LVH is an important predictor for cardiovascular disease and sudden death in the general population. ${ }^{22-24)}$ Various studies, including the Framingham Study, ${ }^{25,26)}$ have shown that the development of ischemic heart disease and cerebral infarction ${ }^{27)}$ is more frequent in patients with LVH than those without. Morbidity and mortality after myocardial infarction ${ }^{28)}$ are also greater in patients with LVH. There have been many reports concerning the relationship between ACE polymorphism and LVH. Schunkert et al. reported an association between ACE polymorphism and LVH identified by ECG in a population-based study. ${ }^{10)}$ Iwai $e t$ al. reported a positive relationship in an out-patient clinic population using 
echocardiography. ${ }^{11)}$ However, little is known about the relationship between ACE gene polymorphism and LVH in which volume overload may be involved. Thus, we examined the relationship between ACE gene polymorphism and LVH in $80 \mathrm{HD}$ patients to assess the involvement of this gene in LVH caused, in part, by volume overload. Previous experimental studies have demonstrated that LVH induced by an aortocaval shunt increased cardiac as well as circulating angiotensin II levels in rats. Moreover, this cardiac hypertrophy and increased angiotensin II were prevented by treatment with an ACE inhibitor or the angiotensin II receptor blocker losartan. ${ }^{29,31)}$ These studies suggest the involvement of the reninangiotensin system in LVH induced by volume overload as well as in that induced by pressure overload ${ }^{32,33)}$ However, we found no significant relationship between ACE gene polymorphism and LVH in HD patients when the relationship was analyzed using a multivariate analytical method.

Several reasons may explain the lack of a significant relationship between LVH and ACE gene polymorphism in HD patients. Firstly, in contrast to LVH seen in essential hypertension, $\mathrm{LVH}$ in $\mathrm{HD}$ patients seems to be attributable to multiple determinant factors, i.e., pressure-overload, volume-overload and other factors which are closely related to renal failure. Hypertension which had existed before the development of renal failure and volume-overload which was associated with renal failure must contribute to LVH to various degrees in HD patients. Furthermore, it is known that the renin-angiotensin system is inappropriately activated in hypertensive patients with renal disease ${ }^{34,35)}$ and that sympathetic nerve activity in patients with renal failure assessed by microneurography is extremely enhanced ${ }^{36)}$ Thus, the complicated involvement of many factors in hypertension and LVH may have made it difficult to assess the contribution of ACE gene polymorphism to LVH.

Although the multivariate analysis did not demonstrate a significant contribution of the ACE gene to LVH, LVH was associated with serum creatinine, male gender, antihypertensive drug treatment, weight gain between two successive HDs and mean blood pressure after HD. The significant contribution of antihypertensive drug treatment and also elevated mean blood pressure after HD to LVH seems to be consistent with the concept that hypertension is an important factor of LVH in HD patients. ${ }^{37,38)}$ As demonstrated in patients with essential hypertension, ${ }^{39}$ ) LVH was also significantly associated with male gender in the present study. Although the reason is not clear, this may reflect the greater prevalence of hypertension in males in the general population. ${ }^{40,41)}$ Also, the difference in gonadism may be a cause since testosterone is known to promote protein synthesis in cardiac myocytes.

In this study, we included patients who had antihypertensive drug treatment that might reduce LVMI. However, even these patients had higher LVMI and 
were found to be associated with LVMI in multiple regression analysis. This is because these patients may be under larger pressure overload than those who did not need to take antihypertensive drugs. This finding also suggests that the HD patient is not merely a simple volume overload model, but also a multifactorial one.

LVH is very important in predicting prognosis among patients with chronic renal failure. In 1995, the Japanese Society for Dialysis Therapy conducted a statistical survey in Japan and received replies from 2866 facilities (99.82\%). ${ }^{21)}$ The survey found a gross annual mortality rate of $9.7 \%$, of which $25.4 \%$ was from heart failure, $13.5 \%$ from cerebrovascular accident and $7.5 \%$ from myocardial infarction. In other words, the cause of death in $46.4 \%$ of the cases was either a cardiovascular or a cerebrovascular event. Several studies have shown that show LVH is strongly associated with cardiovascular or cerebrovascular events in chronic renal failure patients. ${ }^{43}$ ) Therefore, it is very important to investigate the cause of $\mathrm{LVH}$ and prevent it. According to the present findings, average weight gain between each dialysis was significantly associated with LVH. Thus, for the prevention of LVH in dialysis patients, not only medical treatment but also a modification of life style is of great importance.

The present study has some limitations. First, the sample volume was relatively small and the $\mathrm{D} / \mathrm{D}$ genotype accounted for only $10 \%$, which might create some bias in subjects. However, the relatively low frequency of the $\mathrm{D} / \mathrm{D}$ genotype might be due to ethnic differences. ${ }^{46)}$ Secondly, we did not use magnetic resonance imaging or electrocardiography but rather echocardiography to calculate left ventricular mass. Estimating left ventricular mass using electrocardiography is thought to be somewhat unreliable ${ }^{47}$ in comparison with the other two methods. At present, although magnetic resonance imaging is thought to produce the highest quality LVMI assessment, it is complicated and expensive. However, since we excluded myocardial infarction and valvular heart disease in order to minimize the estimation error for left ventricular mass, our estimation of left ventricular mass may be adequate.

In conclusion, the present findings support the concept that the HD patient can be not only a volume-overload but also a pressure-overload model because antihypertensive drug administration and weight gain between each hemodialysis influence left ventricular mass in these patients. However, ACE gene polymorphism has little association with left ventricular hypertrophy in these patients, suggesting that this polymorphism is not involved in left ventricular hypertrophy in $\mathrm{HD}$ patients. 


\section{ACKNOWLeDGMents}

We would like to thank the patients for their cooperation and our nursing staff for their support.

\section{REFERENCES}

1. Levy D, Garrison RJ, Savage DD, Kannel WB, Castelli WP. Prognostic implications of echocardiographically determined left ventricular mass in the Framingham Heart Study. N Engl J Med 1990; 322: 1561-6.

2. Levy D, Garrison RJ, Savage DD, Kannel WB, Castelli WP. Left ventricular mass and incidence of coronary heart disease in an elderly cohort: The Framingham Heart Study. Ann Intern Med 1989; 110: $101-7$.

3. U.S. Renal Data System: USRDS 1991 Annual Report. Bethesda, The National Institute of Diabetes and Digestive and Kidney Diseases 1991.

4. Canadian Organ Replacement Register: 1991 Annual Report. Hospital Medical Records Institute, Don Mills, Ontario, April 1993.

5. Fassbinder $\mathrm{W}$, Brunner FP, Brynger $\mathrm{H}$, et al. Combined report on regular dialysis and transplantation in Europe XX, 1989. Nephrol Dial Transplant 1991; 6 (Suppl 1): 5-35.

6. Ishigami $\mathrm{T}$, Umemura $\mathrm{S}$, Iwamoto $\mathrm{T}$, et al. Molecular variant of Angiotensin gene is associated with coronary atherosclerosis. Circulation 1995; 91: 951-4.

7. Cambien F, Poirier O, Lecerf L, et al. Deletion polymorphism in the gene for angiotensin-converting enzyme is a potent risk factor for myocardial infarction. Nature 1992; 359: 641-4.

8. Pinto YM, Van Gilst WH, Kingma JH, Schunkert $H$. Deletion-type allele of the angiotensin-converting enzyme gene is associated with progressive ventricular dilation after anterior myocardial infarction. J Am Coll Cardiol 1995; 25: 1622-6.

9. Nakai K, Itoh C, Miura Y, et al. Deletion polymorphism of the angiotensin I-converting enzyme gene is associated with serum ACE concentration and increased risk for CAD in the Japanese. Circulation 1994; 90: 2199-202.

10. Schunkert $\mathrm{H}$, Hense $\mathbf{H W}$, Holmer SR, et al. Deletion polymorphism in the angiotensin converting enzyme gene is a strong risk factor for left ventricular hypertrophy in humans. N Engl J Med 1994; 330: 1634-8.

11. Iwai $\mathrm{N}$, Ohmichi $\mathrm{N}$, Nakamura $\mathrm{Y}$, Kinoshita $\mathrm{M}$. DD genotype of the angiotensin-converting enzyme gene is a risk factor for left ventricular hypertrophy. Circulation 1994; 90:2622-8.

12. Raynolds MV, Bristow MR, Bush EW, et al. Angiotensin-converting enzyme DD genotype in patients with ischaemic ar dilated cardiomyopathy. Lancet 1993; 342: 1073-5.

13. Marcus HS, Barley J, Lunt R, et al. Angiotensin-converting enzyme gene deletion polymorphism: a new risk factor for lacunar stroke but not carotid atheroma. Stroke 1995; 126: 1329-33.

14. Doria A, Warram JH, Krolewski AS. Genetic predisposition to diabetic nephropathy. Diabetes 1994; 43: $690-5$.

15. Ohishi M, Fujii K, Minamino T, et al. A potent genetic risk factor for restenosis. Nat Genet 1993; 5 : $324-5$.

16. Lindpaintner $\mathrm{K}$, Pfeffer MA, Kreutz R, et al. A prospective evaluation of an angiotensin-converting enzyme gene polymorphism and the risk of ischemic heart disease. $\mathrm{N}$ Engl J Med 1995; 332: 706-11.

17. Kupari M, Perola M, Koskinen P, Virolainen J, Karhunen PJ. Left ventricular size, mass, and function in relation to angiotensin-converting enzyme gene polymorphism in humans. Am J Physiol 1994; 267: $\mathrm{H} 1107-\mathrm{H} 1111$.

18. Ori Y, Korzets A, Katz M, Perek Y, Zahavi I, Gafter U. Haemodialysis arteriovenous access: a prospective haemodynamic evaluation. Nephrol Dial Transplant 1996; 11: 94-7.

19. Devereux RB, Reichek N. Electrocardiographic determination of left ventricular mass in man: anatomic validation of the method. Circulation 1977; 55: 613-8.

20. Ishigami $\mathrm{T}$, Iwamoto $\mathrm{T}$, Tamura $\mathrm{K}$, et al. Angiotensin I converting enzyme (ACE) gene polymor- 
phism and essential hypertension in Japan: ethnic difference of ACE genotype. Am J Hypertens 1995; 8: 95-7.

21. The Japanese Society for Dialysis Therapy. An overview of regular dialysis treatment in Japan (as of Dec. 31, 1995). J Jpn Soc Dial Ther 1997; 30: 1-25.

22. Bayes-Genis A, Guindo J, Vinolas $\mathbf{X}$, et al. Cardiac arrhythmias and left ventricular hypertrophy in systemic hypertension and their influences on prognosis. Am J Cardiol 1995; 76: 54D-59D.

23. de Simone G, Devereux RB, Koren MJ, Mensah GA, Casale PN, Laragh JH. Midwall left ventricular mechanics: an independent predictor of cardiovascular risk in arterial hypertension. Circulation 1996; 93: 2: 259-65.

24. Muiesan ML, Salvetti M, Rizzoni D, Castellano M, Donato F, Agabiti-Rosei E. Association of change in left ventricular mass with prognosis during long-term antihypertensive treatment. J Hypertens 1995; 13: 10: 1091-5.

25. Levy D, Garrison RJ, Savage DD, Kannel WB, Castelli WP. Prognostic implications of echocardiographically determined left ventricular mass in the Framingham Heart Study. N Engl J Med 1990; 322: 1561-6.

26. Levy D, Garrison RJ, Savage DD, Kannel WB, Castelli WP. Left ventricular mass and incidence of coronary heart disease in an elderly cohort: the Framingham Heart Study. Ann Intern Med 1989; 110: $101-7$.

27. Levy D, Plehn JF, Wolf PA, et al. Left ventricular mass and risk of stroke in men. Circulation 1987; 76: Suppl IV: IV -143 (abstract).

28. Kaplinsky E. Significance of left ventricular hypertrophy in cardiovascular morbidity and mortality. Cardiovasc Drugs Ther 1994; 8 Suppl 3: 549-56.

29. Ruzicka M, Yuan B, Leenen FHH. Effects of enalapril versus losartan on regression of volume overload-induced cardiac hypertrophy in rats. Circulation 1994; 90: 484-91.

30. Ruzicka M, Leenen FHH. Relevance of blockade of cardiac and circulatory angiotensin-converting enzyme for the prevention of volume overload-induced cardiac hypertrophy. Circulation 1995; 91: 169.

31. Ruzicka M, Skarda V, Leenen FHH. Effects of ACE inhibitors on circulation versus cardiac angiotensin II in volume overload-induce cardiac hypertrophy in rat. Circulation 1995; 92: 3568-73.

32. Rockman HA, Wachhorst SP, Mao L, Ross J Jr. ANG II receptor blockade prevents ventricular hypertrophy and ANF gene expression with pressure overload in mice. Am J Physiol 1994; 266: 246875.

33. Baker KM, Chernin MI, Wixson SK, Aceto JF. Renin-angiotensin system involvement in pressureoverload cardiac hypertrophy in rats. Am J Physiol 1990; 259: H324-H332.

34. Ritz E, Koomans HA. New insights into mechanisms of blood pressure regulation in patients with uraemia. Nephro Dial Transplant 1996; 11 Suppl 2: 52-9.

35. Letizia C, Mazzaferro S, Morabito S, et al. Response of serum angiotensin converting enzyme, plasma renin activity and plasma aldosterone to conventional dialysis in patients on chronic haemodialysis. Int Urol Nephrol 1995; 27: 465-70.

36. Hansen J, Victor RG. Direct measurement of sympathetic activity: new insights into disordered blood pressure regulation in chronic renal failure. Curr Opin Nephrol Hypertens 1994; 3: 636-43.

37. Ma KW, Greene EL, Raij L. Cardiovascular risk factors in chronic renal failure and hemodialysis populations. Am J Kidney Dis 1992; 19: 505-13.

38. Ritz E, Koch M. Morbidity and mortality due to hypertension in patients with renal failure. Am J Kidney Dis 1993; 21 (5 Suppl 2): 113-8.

39. Richard SC, Ronald JP, Pentti R, Peter H, Philip RL. Relation between electrocardiography and echocardiography for left ventricular mass in mild systemic hypertension (Results from Treatment of Mild Hypertension Study). Am J Cardiol 1995; 75: 1233-8.

40. Dustan HP. Gender differences in hypertension. J Hum Hypertens 1996; 10: 337-40.

41. Fujimoto W, Boyko EJ, Leonetti DL, Bergstrom R, Newell ML, Wahl PW. Hypertension in Japanese Americans: the Seattle Japanese-American Community Diabetes Study. Public Health Rep 1996; 111 (Suppl 2): 56-8.

42. Kinson GA, Layberry RA, Hebert B. Influences of anabolic androgens on cardiac growth and me- 
tabolism in the rat. Can J Physiol Pharmacol 1991; 69: 1698-704.

43. Silberberg JS, Barré PE, Prichard SS, Snidermann AD. Impact of left ventricular hypertrophy on survival in end-stage renal disease. Kidney Inter 1989; 36: 2, 286-90.

44. Parfrey PS. Cardiac and cerebrovascular disease in chronic uremia. Am J Kidney Dis 1993; 21: 7780.

45. Foley RN, Parfrey PS, Hamett JD, Kent GM, Murray DC, Barre PE. The prognostic importance of left ventricular geometry in uremic cardiomyopathy. J Am Soc Nephrol 1995; 5: 2024-31.

46. Ishigami $\mathrm{T}$, Iwamoto $\mathrm{T}$, Tamura $\mathrm{K}$, et al. Angiotensin 1 converting enzyme (ACE) gene polymorphism and essential hypertension in Japan: ethnic difference of ACE genotype. Am J Hypertens 1995; 8: 95-7.

47. Sahn DJ, DeMaria A, Kisslo J, Weyman A. Recommendations regarding quantitation in M-mode echocardiography: results of a survey of echocardiographic measurements. Circulation 1978; 58: 107283. 